The iodine number of the oil supposed to have been used on the tops at the mill was 84.3 ; assuming that the change was the sane as in the laboratory, that upon the tops should not have been below 63 or ccrtainly should not have reached 53-54, as both my determinations and that of the mills chemist showed.

The work corroborates that of Ballantyne and shows that except when spread out in a finely divided condition as upon cotton, olive oil changes but little on exposure to the air or heat.

The ligh saponification numbers, $207-221$, indicate that the oil has undergone oxidation and also the entire absence of any unsaponifiable or mineral oil. It would seem from these results that the oil used 11pon the tops was most likely lard oil; had it not been for the possibility of cholesterol in the wool this could have been slown by a test for cholesterol in the extracted oil.

In conclusion, the writer wishes to express his indebtedness to $\mathrm{Mr}$. H. S. Bailey, by whom the analytical work was performed.

Massachusetts Institete of ThehNology, BOSTON, MASS.

\title{
THE EFFECT OF TEMPERATURE ON THE RESPIRATION OF APPLES.
}

\author{
BY FRED W. MORSE. \\ Received February I7, I908.
}

While engaged in an investigation of the effects of different methods of storage on the chemical composition of apples, it was found impracticable with the methods of analysis in common use to determine the variations produced by comparatively small changes in temperature, or in other words, whether $32^{\circ} \mathrm{F}$ or $45^{\circ} \mathrm{F}$ affected the composition of the fruit in a different ratio.

This difficulty was due to the fact of the destruction of some of the apple constituents by respiration, which could be easily deduced from the exhalation of carbon dioxide and water, and the practically constant proportions of water and dry matter which existed in spite of a steady loss of water, and decrease in weight.

It seemed possible that the rate of chemical change might be measured by determining the rate of exhalation of carbon dioxide. Some simple experiments with fruit under bell jars, over mercury, and over water, soon showed that temperature had a very marked effect on the exhalation of the respiratory products.

A respiration apparatus was planned and constructed as follows: 'The chamber in which the fruit was to be placed was a cylindrical vessel of copper supported by a tripod in an upright position. The bottom of the cylinder was formed like a funnel ending in an outlet tube of brass 
to connect with absorption apparatus. The top of the cylinder was closed by a disc of glass, which rested on a narrow shelf soldered to the inner wall of the cylinder. An inlet tube entered the cylinder just beneath the shelf.

The dimensions of the cylinder were, diameter $20 \mathrm{~cm}$., height $25 \mathrm{~cm}$., and conical bottom $5 \mathrm{~cm}$. in depth. The shelf for the glass plate was $2 \mathrm{~cm}$. below the upper edge. The total volume was a little more than 6 liters. The inlet and outlet tubes were $6 \mathrm{~mm}$. in diameter.

The respiration chamber was placed inside a larger galvanized iron tank, which could be filled with ice or water in order to control the temperature. The outlet tube was passed through a tubulure near the bottom of the outer vessel. The inlet tube was passed through a hole in the cover of this vessel, led to a point near its bottom, then coiled around the tripod and, finally, soldered to the inlet orifice near the top of the respiration chamber.

Air, before entering the chamber, would thus be brought to the temperature of the surrounding tank, and the carbon dioxide would fall and accumulate in the funnel-shaped bottom. A slow current of air would maintain a constant temperature within the respiration chamber and the carbon dioxide would be readily removed because of its density.

The air was freed from carbon dioxide before entering the chamber by passing it through a solution of potassium hydroxide. The exhaled carbon dioxide was collected in two absorption tubes connected with the outlet. The first tube contained a $2 n$ per cent. solution of potassium hydroxide and the second tube a standard solution of barium hydroxide. The determinations were made by titrating the alkaline solutions with half-normal hydrochloric acid.

In titrating the potash solution, phenolphthalein was added as an indicator and the acid added until neutral, then methyl orange was added and an exact measurement made of the amount of standard acid now required to neutralize the potassium hydrogen carbonate. The barium solution was titrated with the standard acid and phenolphthalein.

In the majority of experiments the potassium hydroxide absorbed all the carbon dioxide.

The procedure in an experiment was as follows:

About 2 kilograms of sound Baldwin apples were placed in the respiration chamber, and the glass disc was firmly sealed in place with putty. A current of air was drawn through the apparatus by means of an aspirator holding about 16 liters of water. The rate of flow was adjusted so that the air would be renewed three or four times during the experiment, and yet not pass too rapidly to permit complete absorption of the gas by the alkaline solution.

Blank experiments were repeatedly made to include the carbon dioxide, 
which might leak in, together with that in the atmosphere of the empty chamber and the amount present in and absorbed by exposing the solutions while filling and emptying the absorption tubes, and titrating. Corrections were then made by deducting results of blank tests from the amounts obtained in experiments with the fruit.

The leakage gave but 2 to $3 \mathrm{mg}$. of carbon dioxide; but the contamination of the solutions was of considerable consequence, requiring about 2.5 cc. of the half-normal acid to correct it.

The earlier experiments were conducted only during the day, because the aspirator was found unreliable in maintaining a continuous current of air. Therefore, each morning, air was drawn rapidly through the chamber until its atmosphere had been renewed repeatedly, before the absorption tubes were attached for the collection of the exhalations.

Later in the season, a larger aspirator was employed by which a continuous run could be maintained for two days or more at a time. Some of the experiments were made at room temperatures, some with the outer tank filled with ice-water, and some with it filled with closely packed ice. No attempt was made to regulate the temperatures closely, during these trials, but readings of a thermometer in the room or in the outer tank were recorded.

Since the weights of fruit and length of time varied with different experiments, the amounts of carbon dioxide were calculated on a common basis of one kilogram of fruit and one hour of time, and the quantities expressed in milligrams.

The data of the different runs follow, with the results arranged in groups, according to the temperatures. The room temperatures and the icewater temperatures ranged through several degrees, but all results are included.

Carbon Dioxide Exhaled by i Kilo of Apples Per Hour.

\begin{tabular}{|c|c|c|c|c|c|c|c|c|}
\hline Room temperat & $\begin{array}{l}18^{\circ} t \\
\text { Hrs. }\end{array}$ & $\begin{array}{l}25^{\circ} \mathrm{C} . \\
\text { Mgs. }\end{array}$ & Medium temp & $\begin{array}{l}\text { ture, } 5 \\
\text { Hrs. }\end{array}$ & $\begin{array}{l}\text { to } 10^{\circ} \mathrm{C} . \\
\mathrm{Mgs} .\end{array}$ & Low tem & $\begin{array}{l}\text { ure, } 0^{\circ} \\
\text { Hrs. }\end{array}$ & $\mathrm{Mgs}$ \\
\hline Oct. I6 & $81 / 2$ & 16.4 & Oct. 22 & 5 & 8.0 & Oct. 29 & 22 & $2 \cdot 3$ \\
\hline Oct. 17 & 5 & 18.7 & Nov, 7 & $6^{1 / 6}$ & $7 \cdot 3$ & Oct. 30 & $61 / 3$ & 2.6 \\
\hline Nov. 5 & $65 / 4$ & 12.6 & Dec. 2 & $5 \pm / 2$ & 8.7 & Nov. 8 & 8 & 3.8 \\
\hline Nov. 6 & $61 / 2$ & 12.6 & Dec. 3 & $61 / 2$ & 9.5 & Mar. 2-4 & $461 / 2$ & 2.4 \\
\hline Nov. 12 & $61 / 4$ & I 8.2 & Dec. 4 & $6 \frac{1}{4 i}$ & 8.8 & Mar. $4-6$ & $553 / 4$ & 2.8 \\
\hline Dec. 9 & $5^{1 / 6}$ & 18.0 & Dee. 5 & $\pi 1 / 2$ & 7.9 & Mar. 9-II & 48 & 2.2 \\
\hline Dec. Io & 6 & 17.9 & Dec. 6 & $51 / 2$ & 9.6 & & & \\
\hline Dec. I I & $61 / 2$ & 23.0 & Mar. $16-18$ & 48 & $5 \cdot 5$ & & & \\
\hline Dec. 12 & $6 \pm / 2$ & 26.7 & & & & & & \\
\hline Feb. $26-28$ & +7 & 17.9 & & & & & & \\
\hline
\end{tabular}

It was invariably noticed that a number of hours was required to bring the apples into equilibrium with the surrounding temperature, hence, when changing from room temperature to that of melting ice, the respira- 
tion would slowly decrease until it reached the normal rate for the latter environment.

The average rate of exhalation of carbon dioxide was $18 \mathrm{mg}$. per kilo an hour at room temperatures, $8.1 \mathrm{mg}$. at medium temperatures, and $2.7 \mathrm{mg}$. at zero.

A comparison of the results obtained at the different temperatures showed that they were not directly proportional to the variations in temperature, but that there was an acceleration of the rate of respiration as the temperature rose, which corresponded to the law of acceleration of chemical action by rise of temperature.

At room temperature, the amount of carbon dioxide per kilo an hour was about 6 times what it was at $0^{\circ}$. The intermediate temperatures gave an average result which was 3 times that of $0^{\circ}$, and not quite onehalf of that at the higher temperatures.

The investigation was now dropped for a time, until an opportunity offered for better control of temperature. Although there was a strong probability that the acceleration of respiration was in accord with the acceleration of chemical action with rise in temperature, there were uncertainties about the actual temperatures involved.

A year elapsed before the investigation was resumed. Particular attention was given to the temperature of the apples between the runs in the respiration apparatus, in order to avoid the lag in temperature change in the apples themselves.

The apples were brought in from a cool storage cellar where the temperature was running between $45^{\circ} \mathrm{F}$ and $50^{\circ} \mathrm{F}$, or $8^{\circ}$ to $10^{\circ} \mathrm{C}$. It was therefore decided to try the temperature of $10^{\circ}$ first, and save the time required to bring the fruit to some other temperature. The temperature of the chamber was maintained by means of ice-water, just enough ice being added from time to time to keep the thermometer in the outer chamber at $10^{\circ}$. The warm room, of course, tended constantly to raise the temperature.

The apparatus was the same used in previous trials. The aspirator was run as rapidly as was consistent with thorough absorption of the carbon dioxide. The same methods of determining carbon dioxide were employed and everything done to make the results comparable with the earlier ones.

The experiments were conducted for several successive days. After the day's run was made, the apples were removed to a large jar and placed in a pail of cold water which sat in the coolest part of the building where the temperature had been noted to remain at about $10^{\circ}$ during the night. In the morning of each day, they were replaced in the respiration apparatus and the experiment thus resumed. On one morning the water was found to have fallen to $0^{\circ}$ and no run was made on that day. 
For the temperature of $0^{\circ}$, the outer tank was kept full of closely packed snow throughout the day. When each day's run was completed the apples were tightly closed in a large jar and buried in a snow-bank out of doors. They were also put out there for about 18 hours before the first run.

Room temperature proved difficult to control. The rooms were hot in the latter part of the day, cool at night and gradually warming during the forenoon. Runs were omitted on days when the morning temperature of the room was below $15^{\circ}$.

The results of the three series of experiments are given below:

Experiment i 1 . Weight of apples, 1428 grams. Temperature $10^{\circ} \mathrm{C}$.

Mar. 15. 6 hours, carbon dioxide $116.6 \mathrm{mg}$.

Experiment 12 . Weight of apples, I 47 grams. lemperature $10^{\circ} \mathrm{C}$.

Mar. IG. Gliours, carbon dioxide $93.5 \mathrm{mg}$.

Mar. I3. G hours, carbon dioxide $85.8 \mathrm{mg}$.

Experiment I3. Weight of apples, 1145 grams. lemperature $0^{\circ} \mathrm{C}$.

Mar. 21. 6 hours, carbon dioxide $38.9 \mathrm{mg}$.

Mar. 22. 6 hours, carbon dioxide $39.6 \mathrm{mg}$.

Mar. 23. 6 hours, carbon dioxide $27.5 \mathrm{mg}$.

Mar, $2+6$ hours, carbon dioxide $36.3 \mathrm{mg}$.

Experiment I4. Weight of apples, I 42 grams. Temperature $20^{\circ}$.

Mar. 25. 6 hours, carbon dioxide $550.2 \mathrm{mg}$.

Mar. 28. 6 hours, carbon dioxide $145.2 \mathrm{mg}$.

Mar. 31. 6 hours, carbon dioxide $54.0 \mathrm{mg}$.

The results for the different temperatures calculated for an hour and a kilogram of fruit are given below:

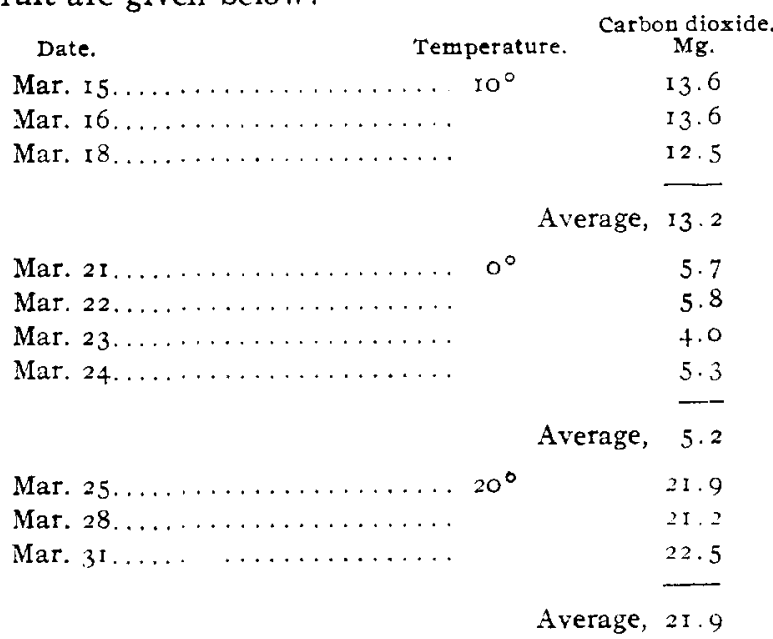


The acceleration from $0^{\circ}$ to $10^{\circ}$ is more marked than that from $10^{\circ}$ to $20^{\circ}$, but the ratio of 2 to I holds practically true and is 4 to $I$ for the rise of $20^{\circ}$.

While this work was in progress there was published by Bigelow, Gore and Howard ${ }^{1}$ a description of respiration experiments with apples where there were two lots, one at $0^{\circ}$ and the other at $15^{\circ}$. These results were given in percentages of the original weights of apples. From their tables it was found that but four dates could be compared, which are given herewith, together with the percentages of carbon dioxide and the ratio between $0^{\circ}$ and $15^{\circ}$.

\begin{tabular}{|c|c|c|c|}
\hline Date. & $0^{\circ}$. & $15^{\circ}$ & Ratio $0^{\circ}: 15^{\circ}$ \\
\hline Jan. 5. & 0.234 per cent. $\mathrm{CO}_{2}$ & 0.794 per cent. $\mathrm{CO}_{2}$ & $1: 3 \cdot 3$ \\
\hline Jan. 27 & 0.308 & 0.899 & $1: 2.9$ \\
\hline Mar. 2. & 0.436 & I. I 22 & $\mathrm{I}: 2.5$ \\
\hline Mar. 30 & 0.484 & I. 375 & $1: 2.8$ \\
\hline
\end{tabular}

The average ratio is $I: 2.9$, which is approximately that of $I: 2$ for a rise of $10^{\circ}$.

All these results show concordance and prove that apples undergo chemical changes fully twice as fast and in some instances three times as fast with a rise of temperature of $10^{\circ}$ between $0^{\circ}$ and $20^{\circ}$, or in other words, at summer temperatures apples will undergo respiratory metabolism from 4 to 6 times as rapidly as in modern cold storage. The low temperatures also prove that ther must be a limit to the keeping quality even there, since respiration and consequent destruction of cell tissues still goes on.

NEW HAMPSHIRE AGRICULTURAL EXPERIMENT STATION, DCRHAM, N. H.

\section{OBSERVATIONS ON THE STABILITY OF LECITHIN.}

BY J. H. I,ONG.

Received February 19, 1908.

Numerous investigations published in the last four or five years on the subject of the preparation of the lecithin compounds from eggs or from animal and vegetable tissues have discussed more or less vaguely the stability of these products under the influence of light, heat, and atmospheric oxidation. It seems to be assumed that the lecithins in general suffer very ready decomposition, but in the literature $I$ am unable to find much that is definite as to the extent of their decompositions which take place under the influences referred to. In the course of certain experiments in other directions I found the need of this information and felt obliged to carry out some experiments to supply the desired data.

At the outset it may be said that the conception of the term "lecithin"

${ }^{1}$ U. S. Dept. Agr., Bur. of Chem., Bull. No. 94, "Studies on Apples." 